\title{
THE HOMONOIA COINS OF ASIA MINOR AND EPHESIANS 1:21
}

\author{
John Paul Lotz
}

\section{Summary}

During the later half of the first century A.D., the politcal climate in the Greek East was characterised by tensions arising from the competition for titles and status between the leading cities of the eastern provinces, especially in Asia Minor. Ephesus, Smyrna, and Pergamon in particular nurtured tense

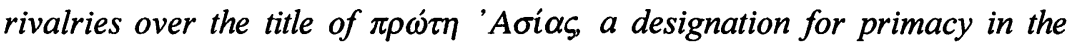

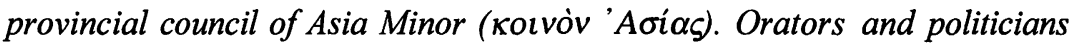
tried to counter the potentially negative consequences these competitions could have on what political power remained to these Greek cities by exhorting the virtues of 'political concord' (ómóvora) in speeches, inscriptions and coins. The homonoia coins of Asia Minor offer us in important insight into the tensions and viscisitudes of city politics in late first century Asia Minor, and help broaden our understanding of the sociopolitical background and context that Paul and his disciples spoke to. Of special interest will be how the homonoia coins of Asia Minor help us in our interpretation of certain symbols and images that occur in Ephesians 1:21, and how these speak to the persistent struggle to achieve peace and concord in the cities of the Greek East under the Roman 'peace', where, according to the writter of the epistle, Caesar and his empire fail to deliver precisely that which Christ and his church are offering: peace and unity.

\section{Introduction}

Speaking for ancient historians almost 50 years ago, A.H.M. Jones noted the importance of the field of numismatics for both classical studies and ancient history, stating that its unique contribution lay in validating the literary evidence.' He noted that coins often

I A.H.M. Jones, 'Numismatics and History' in Essays in Roman Coinage Presented to Harold Mattingly, ed. R.A.G. Carson and C.H.V. Sutherland (Oxford: OUP, 1956), p. 14. 
represented important events in ancient history, such as the founding of a city, or the annexing of a province under the Romans, and that the various issues enhanced the historian's understanding of the official political dimensions of selected high points in the history of the ancient world. ${ }^{2}$ Since then, the fields of archaeology, epigraphy, papyrology and numismatics have continued to grow and develop with the influx of new data, material, and finds from sites that provide classical scholars with new insights into the complexities of life in the ancient world. For the biblical scholar, many of these advances in our understanding of the ancient world are relevant for the work of interpreting and developing our understanding of biblical texts as well as the forces that may have influenced how the writers and the readers of the ancient texts heard and understood their message. ${ }^{3}$

In recent years, a wealth of material has been consolidated into accessible resources for the biblical scholar. ${ }^{4}$ Interdisciplinary projects have yielded helpful tools for approaching the ancient world in fresh ways that promise to mandate further research for biblical scholars interested in doing context-sensitive exegesis. They avoid the cumbersome and (often) forced recycling of hypotheses and theories that have in recent years attracted much of the field's scholarly attention. ${ }^{5}$ This joining of forces of scholars and specialists from various disciplines offers many advantages for contemporary NT scholars who are looking for new approaches to texts and problems that have been exhaustively interpreted over the last five decades.

2 Ibid.

3 One need only mention finds like those at Qumran and Nag Hammadi to emphasise the importance for biblical scholarship of advances and new materials from the field of papyrology and other related disciplines.

4 Classic samplings, such as C.K. Barrett's The New Testament Background: Selected Documents (London: SPCK, 1987), and Everett Ferguson's Backgrounds of Early Christianity (Grand Rapids: Eerdmans, 1993), have been greatly expanded by efforts such as New Documents Illustrating Early Christianity, 6 vols. (North Ride, NSW: Ancient History Documentary Research Center, Macquarie University, 1989), The Book of Acts in Its Ancient Literary Setting, 6 vols. ed. B.W. Winter and A.D. Clarke (Grand Rapids: Eerdmans, 1993) as well as the Harvard Theological Studies series on various NT cities: Ephesos: Metropolis of Asia, ed. H. Koester (Valley Forge, PA: Trinity Press International, 1995); Pergamon: Citadel of the Gods, ed. H. Koester (Valley Forge, PA: Trinity Press International, 1998).

5 For instance, much valuable work on the Synoptic Problem has been obscured by the excessive amount of literature on the topic. See also, David L. Dungan, History of the Synoptic Problem (New York: Doubleday, 1999). 
Recently, C.E. Arnold has argued that evidence from new magical papyri discovered in Egypt ${ }^{6}$ helps support the idea that a developed tradition of black magic lay behind many of the comments the author of Ephesians makes regarding 'powers and authorities'.7 His valuable use of recently discovered papyri offers a culturally nuanced view that is a helpful example of moving beyond a strictly theological interpretation of some of the texts in Ephesians.

Along with religious and cultural influences on the writer and recipients of the letter to the Ephesians, there were also fundamental political influences that helped shape the way those early Christians understood themselves. One important source for our understanding of the political dimensions affecting civic life in first century Asia Minor comes from the growing body of numismatic evidence gathered from various cities. ${ }^{8}$ Political slogans, foundation sagas, city gods and religious symbols have all appeared on coins from the Hellenistic through to the imperial period. ${ }^{9}$ One particular type of coin legend may have a special bearing on the interpretation of some passages in the epistle to the Ephesians. The homonoia coins of Asia Minor from the late first through to the third centuries A.D., reflect important aspects of the political climate in western Asia Minor that would have been familiar issues to many of the citizens of the major cities of Asia. ${ }^{10}$

The civic and political life of the Greek polis was a powerful force in shaping the mentality and world-view of its inhabitants, even after Roman hegemony had sterilised some of the explosiveness of city politics in the Greek East, and should not be minimised when considering what forces and influences affected the daily lives of most of the citizens. ${ }^{11}$ The Greek city was the fundamental structure of social cohesion and identity in the ancient world and was the essential context for ideas of statecraft, citizenship, and social well-

6 See, The Greek Magical Papyri in Translation, Including the Demotic Spells, ed. Hans Dieter Betz (Chicago: University of Chicago Press, 1986).

7 C.E. Arnold, Ephesians, Power and Magic (Cambridge: CUP, 1989).

8 See especially, P.R. Franke, $Z u$ den Homonoiamunzen Kleinasiens, in: Stuttgarter Kolloquium zur historischen Geographie des Altertums 1, 1980 (Bonn: Habelt, 1987), pp. 81-102.

9 S. Mitchell, Anatolia, vol. 1 (Oxford: Clarendon, 1993), pp. 207ff.

10 Catalogue of the Greek Coins of Ionia; Catalogue of Greek Coins in the British Museum (BMC), Barclay V. Head (London: Trustees of the British Museum, 1982), p. 250, no. 131.

11 See F. de Coulanges, The Ancient City (New York: Doubleday, 1956), pp. $201 \mathrm{ff}$. 
being. ${ }^{12}$ The idea of the city was so particular in the mind of the Greeks that their inability to put aside internecine disputes and conflicts and unite eventually led to their decline and loss of political independence. ${ }^{13}$ Socrates was a victim of the particular self-identity of Athens and was condemned to death for "not believing in the gods the City believes in'. ${ }^{14}$ By the end of the first century A.D., the cultural dimensions of most Greek cities were still intact, and the Greek literature of the Second Sophistic recorded a rise in social and political discord between the leading Greek cities in Asia Minor as many sought to re-affirm their status and political identity within the context of Roman rule, and over-against each other. Aside from inscriptions and some valuable literary evidence, ${ }^{15}$ much helpful work has been done in the area of numismatics which adds a great deal to our ability to understand the context behind many of the problems faced by the Greek cities of the East. ${ }^{16}$ How aspects of city politics may have influenced Christians locally will be explored in the context of the many attempts to negotiate 'political concord' (ópóvol $\alpha$ ) between the leading cities of Asia Minor towards the end of the first century.

\section{Rivalry and discord: Homonoia politics}

The Greek cities of the East habitually faced the threat of conflict and discord with one another, as well as strife inside their own walls. Tensions within the cities between the various classes and parties led to the conflicts reflected in the struggle for power between the oligarchs and the democrats of the fifth and fourth centuries throughout the Aegean world. ${ }^{17}$ The divide between rich and poor

12 Ibid., p. 202.

13 R. Bernhardt, Polis und römische Herrschaft in der späten Republik (149-31 v. Ch.), Untersuchungen zur antiken Literatur und Geschichte; 21 (Berlin: de Gruyter, 1985).

14 Cited in A.R. Burn, The Warring States of Greece (London: Thames \& Hudson, 1968), p. 106.

15 Esp. Dio Chrysostom, Or. XXXVIII-XLII, A. Aristides Or. XXIII, and Plutarch Prec. Ger. Reip.

16 The standard collections include: H. Mattingly and R. Carson, Coins of the Roman Empire in the British Museum, 6 vols. (London: Trustees of the British Museum, 1923-1962); Catalogue of Greek Coins in the British Museum; B.V. Head, Catalogue of Greek Coins of Ionia (London: 1901), Lydia (1902), Phrygia (1906).

17 Bernhardt, R., Polis und Römische Herrschaft in der späten Republik (149. 31 v. Ch.) (Berlin, 1985), p. 122. These conflicts eventually neutralised their 
was immense, and the threat of sedition ( $\sigma \tau \alpha$ or $)_{\text {) }}$ always hovered over the political landscape. 18 Conflict lay at the heart of city politics, and can be seen perhaps in its clearest form at the height of the classical city in Greece in the inter-city rivalry between Sparta and Athens which led to the Peleponesian Wars and eventually compromised Greek sovereignty in the Aegean. ${ }^{19}$ The rivalry between Athens and Sparta was only endemic of a culture of discord that characterised the Greek cities, and even after foreign rule was established over the cities, little changed, as new ways to compete with one another were pursued..$^{20}$

As persistent as the struggles and conflicts were, and however unattainable peace seemed to be, the Greeks had an ideal after which they strove. As early as Thucydides, and well into the Graeco-Roman period in Plutarch, Dio Chrysostom, and Aristides, examples of moralists and philosophers exhorting the virtues of concord and peace among their fellow citizens are not uncommon. ${ }^{21}$ Many virtues were divinised, so that Concordia in Rome and Homonoia in Greece were not only political ideals but goddesses personifying agreement within the political structures of the city. They represented in religious symbol the ideal which both the Emperor and the philosophers admonished their followers to imitate. ${ }^{22}$

In the first century A.D., Plutarch shows an appreciation for the value of homonoia in civil administration. Citing history as his precedent, Plutarch noted the example of Solon as a personality worthy of imitation by anyone beginning public life as a politician. Solon's virtue lay in being able to bring about homonoia between the conflicting parties in Athens without entangling himself in their discord, and so was able to orchestrate their reconciliation. ${ }^{23}$ Plutarch felt that the greatest responsibility of a politician was to instil 'concord and friendship among those who dwell together' and

political unity, and contributed to the demise of Greek independence.

18 Finley, M.I., The Ancient Greeks (London: Penguin, 1977), p. 59.

19 Finley, Ancient Greeks. Even after the War and the defeat of Athens, otóols was the rule as Greek cities fought one another consistently. There was some talk of a common peace in the 4th century B.C., but after Sparta's devastating defeat at the hands of Thebes, a virtual pandemonium of conflict followed suit. 20 Tarn, W., and Griffith, G., Hellenistic Civilization (London: E. Arnold, 1952), p. 66.

21 Dio Ch., Or. 38.11; Plut., Praec.Ger.Reip. (824B); Arist. 23.29.

22 Purcell, N., 'Concordia' in The Oxford Classical Dictionary, third ed., ed. by

S. Hornblower, A. Spawforth (Oxford: Clarendon, 1996), pp. 375-76.

23 Plut. Praec.Ger.Reip. (805E). 
to banish strife, discord and enmity. ${ }^{24}$ Plutarch was well aware of the new political hierarchies that dominated the political life of the Greek cities, and he warned of the necessity for politicians to be mindful of Roman sovereignty. ${ }^{25}$ It was, under the umbrella of Roman domination, the politician's greatest prize to establish a quiet and harmonious (ómóvotas) political climate among his fellow citizens, in light of the present weakness in Greek political life. ${ }^{26}$

Dio Chrysostom, who was a contemporary of Plutarch and a resident of the Province of Bythinia-Pontus, has left us with the most comprehensive discussion of homonoia as a political virtue. ${ }^{27}$ For Dio, homonoia reached from the personal to the cosmic dimensions. It was both the friendship and harmony that existed between a husband and his wife, between brothers, and between friends, as well as the fundamental bonds which held together the very elements of the universe. ${ }^{28}$ In Dio's orations, the political necessity for homonoia that life in first century Asia Minor mandated, was coloured with metaphysical qualities that connected the idea with the golden past of ancient Greece. Dio frequently spoke on the nature of homonoia, and was solicited several times to broker peace between Nicomedia and Nicaea, which were leading rivals in Dio's native province of Bythinia-Pontus, and between his own home city of Prusa and its rival, Roman Apamaea. ${ }^{29}$ Dio contrasted strife and discord with peace and concord, and Dio's numerous examples of how the two affected the welfare of the cities reveal how prevalent and complex an issue the political tensions of the first century were. ${ }^{30}$ Dio's Orations described both civil and domestic conflicts within cities as well as the rivalries and enmities that raged between them, and though he often advises its citizens to embrace homonoia as a political virtue, he also prays to the gods on behalf of concord. ${ }^{31}$ This personification of political virtues was common in both Greek

24 Plut. Praec.Ger.Reip. (824D).

25 Plut. Praec.Ger.Reip. (814A-C).

26 Plut. Praec.Ger.Reip. (824E).

27 Jones, C.P., The Roman World of Dio Chrysostom (Cambridge, Mass., London: Harvard University Press, 1978), p. 94.

28 Dio Ch. Or. 38.11, 15.

29 See Dio Ch. Or. 38, Or. 40.

30 Dio Ch. Or. 39.2-4.

31 Dio Ch. Or. 38.51. In his appeal to the city of Nicaea for internal concord, Dio offers prayers to an abbreviated collection of Greek gods including Aphrodite Philia, and Homonoia. 
and Roman religious life and probably began to develop in the case of ópóvota as early as the fourth century B.C. ${ }^{32}$
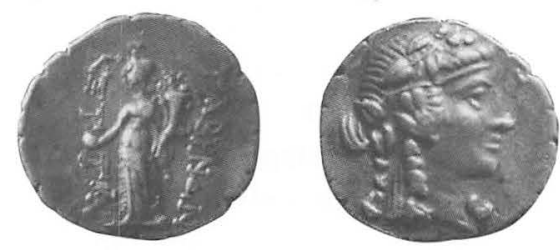

The Goddess Homonoia holding cornucopia in her left hand (Reproduced by ihe kind permission of the Fitzwilliam Museum, Cambridge)

The cult of 'Opóvora has been attested from as early as the fourth century B.C. onwards throughout Greece, as inscriptions on altars at Olympia and Athens verify. ${ }^{33}$ Statues to Opóvota are mentioned in some inscriptions in Asia Minor, although it is not always easy to identify whether these inscriptions refer to Opóvora as a goddess, or to the restoration of friendly relations between parties within cities, which was more common. ${ }^{34}$ There is evidence for a religious expression of homonoia in the cult of 'Opóvora of the Hellenes and

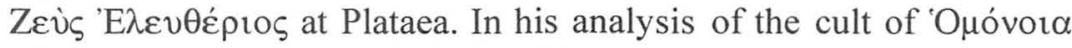
of the Hellenes at Plataea, W.C. West thinks that the combination

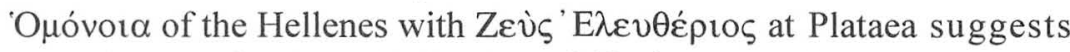

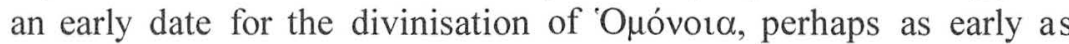
Phillip II, or under Alexander the Great. ${ }^{35}$ Though the fundamental meaning of ópóvola in the fifth and fourth centuries involved harmony at the local level between rival political factions within a city, West notes that both Lysias and Isocrates expand their use of ópóvora to refer to concord between cities in their arguments for a common war against the Persians. ${ }^{36}$ Plataea was the sight of the famous battle in the fifth century where the Persians were defeated by a united Greek front, and the city's rebuilding under Alexander the Great may have been the occasion when the cult of homonoia was incorporated into the existing cult of Zeus. ${ }^{37}$ In the summer of 324 B.C. at Opis, Alexander celebrated the reconciliation of his Macedonian troops with his Persian soldiers in a lavish feast for

32 Shapiro, 'Homonoia' in Lexicon Iconographicum Mythologiae Classicae (Zurich: Artemis, 1981), p. 476.

33 Shapiro, p. 477.

34 Shapiro, p. 477.

35 West, W.C., 'Hellenic Homonoia and the New Decree from Plataea' GRBS

18 (1977), 307-319.

36 West, pp. 309, 313 .

37 West, pp. 316-17. 
9,000 men where he prayed for homonoia between the Persians and Macedonians as partners in the new government. ${ }^{38}$ Alexander's use of homonoia in his prayer reflects a familiarity with both the political and religious uses of the idea and suggests an even broader use of the term than Isocrates envisioned.

Although coins bearing the image of the goddess 'Opóvora are rare, ${ }^{39}$ the ideal was often stressed in religious terms on coins depicting the gods of rival cities clasping hands as a symbol of restored friendship and harmony. ${ }^{40}$ Political relationships were often expressed in religious terms, as the ample evidence for the popularity of the Imperial cults in Asia Minor suggests. ${ }^{41}$

\section{Inter-city rivalry in Asia Minor}

By the first century A.D., the leading cities of Asia Minor, Pergamon, Ephesus, and Sardis were engaged in heated posturing and

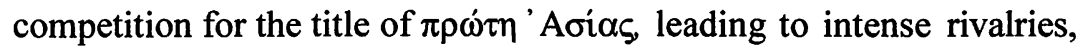
and wasteful city building projects and imperial embassies. ${ }^{42}$ Conflict, though no longer armed, was still possible under Roman rule, and the titular rivalries between the leading cities of Asia Minor offer an important insight into the delicate balance between compliance and resistance which Greeks negotiated under Roman rule during the first century. Though limited in their political manoeuvrability, the leading cities of the province expressed their civic patriotism and identity through attempts to secure status and privilege from the Romans, and envy from each other through the many public benefactions and building projects which decorated their city's landscape. ${ }^{43}$

One of the central features of this rivalry was the privilege of acquiring an imperial cult temple, and thus reaping the privileges of Roman favour and the economic prosperity related to the meeting of

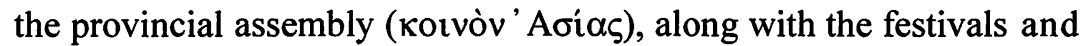

38 O'Brien, J.M. Alexander the Great (London: Routledge, 1992), p. 207.

39 Shapiro and Holscher, LIMC vol. 2, pp. 332-33. For coins bearing the image of a seated image of the goddess 'Oróvora.

40 Price, S.R.F., Rituals and Power: The Roman Imperial Cult in Asia Minor (Cambridge: CUP, 1984), p. 127.

41 Price, p. 131.

42 U. Kampmann, 'Homonoia politics in Asia Minor', in Pergamon, Citadel of the Gods, ed. H. Koester, Valley Forge, PA, 1998, p. 385; Dieter Kienast, 'Die Homonoia Verträge in der römischen Kaiserzeit' JNG 14 (1964), p. 58.

43 S. Mitchell, Anatolia, vol. 1 (Oxford: Clarendon Press, 1993), p. 210. 
athletic competitions which were held in honour of the emperor. ${ }^{44}$ Other titles included being able to call one's city $\mu \eta \tau \rho$ ó $\pi \circ \lambda \iota \varsigma$, or to be named an assize-district, where the provincial governors would hear lawsuits and try cases. ${ }^{45}$ But by the end of the first century A.D., the most coveted title was that of temple warden of the imperial

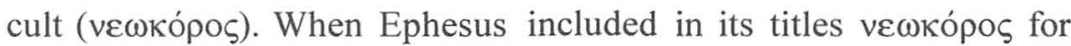
the Temple of the Sebastoi in A.D. 89/90, neighbouring cities, especially Pergamon, had to amend their own city titles to reflect the Ephesian boast. 46
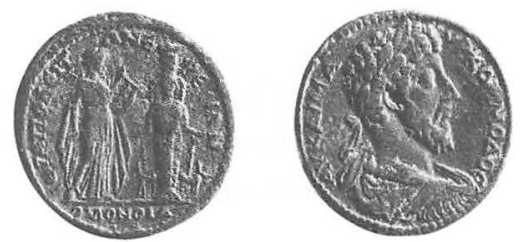

Homonoia coin struck between Hierapolis and Ephesus portraying the cities' divinities (Reproduced by the kind permission of the British Museum)

L. Weber, who has catalogued many of the homonoia coins from Hierapolis, notes that the development of the neocorate beginning in the reign of Augustus coincided with a rise in the appearance of homonoia coins minted by the cities of Asia Minor. 47 Though the first homonoia coins to appear in the Augustan period are from Pergamon and Sardis, by the reign of Domitian a fully popularised expression of homonoia coins became characteristic of the political interactions between many of the cities of Asia Minor. ${ }^{48}$ The relationship between the competition for Imperial cult temples as honorific titles, and the minting of coins advertising homonoia between rival cities reveals how homonoia was often used as a slogan for brokering concord amidst the harsh political realities of the late first century.

The acquisition of an Imperial cult temple fundamentally heightened the political status of the city that maintained one. Since

44 Merkelbach, 'Der Rangstreit der Städte Asiens und die Rede des Aelius Aristides über die Eintracht' in ZPE 32 (1978), pp. 287ff.; Steven Friesen, 'The Cult of the Roman Emperors in Ephesos' in Ephesos: Metropolis of Asia, ed. H. Koester (Valley Forge, PA, 1995), pp. 238ff.

45 T.R.S. Broughton, 'Roman Asia Minor', in F. Tenney, ed., An Economic Survey of Ancient Rome, 6 vols. (Baltimore: Johns Hopkins Press, 1938), pp. 740-41.

46 See S. Friesen, p. 235, for discussion and sources.

47 L. Weber, 'Die Homonoia Munzen des phrygischen Hierapolis' JIAN 14 (1912), pp. 115ff.

48 Weber, p. 115. 
the substance of the rivalries in first century Asia Minor was titular, the legends on many coins describing a city's status did so in terms of its official titles. These titular rivalries were common fare for the leading cities of Asia and were the context for many of the homonoia issues that were minted between them. ${ }^{49}$ Kampmann's helpful work on Pergamon reveals how the cities in Asia Minor not only jockeyed for the limited amount of political power left to them, but also how homonoia politics was a form of inter-city diplomacy that allowed the cities some form of self-expression and differentiation under Roman rule. ${ }^{50}$ Although Dietmar Kienast's theory of an actual legal nature to homonoia politics has been ruled out by several leading scholars, ${ }^{51}$ the connections he makes between the earlier treaties of Greek cities during the Hellenistic period and the homonoia diplomacy of the first century establishes a line of continuity for the important role of negotiation between the Greek cities in general. 52

While negotiating the power structures of late first and second century Asia Minor was the particular prerogative of the provincial Kotvóv, cities actively competed for the titles and honours that would move them up the hierarchies of privilege represented at the annual meetings. ${ }^{53} \mathrm{~A}$ central feature of the provincial meeting was the sacrifice and procession that began from the temple of the Imperial cult. It was very often at these festivals, and especially the procession, where old rivalries were re-awakened as delegations jockeyed for the right to lead the procession. ${ }^{54}$ It is in this context that many homonoia coins bear witness to the efforts made to secure both status and agreement between the rival cities, and a substantial body of evidence offers an insight into how common a theme intercity homonoia may have been. ${ }^{55}$ Many of these coins may have been issued at the provincial feast, where the leading cities would

49 Kienast, 'Die Homonoia Verträge', p. 53.

50 U. Kampmann, Die Homonoia-Verbindungen der Stadt Pergamon (Saarbrucken: Saarbrucker Druckerei und Verlag, 1996), pp. 92ff.

51 A.A.R. Sheppard, 'Homonoia in the Greek cities of the Roman Empire', Anc. Soc. 12 (1984), 229-53.

52 D. Kienast, ' $\mathrm{Zu}$ den Homonoia-Vereinbarungen in der römischen Kaizerzeit', ZPE 109 (1995), pp. 279ff.

53 Dio Chrysostom encourages Nicomedia and Nicaea to embrace ó $\mu$ óvora with each other, and so secure greater leverage against corrupt provincial governors. Or. 38.40ff. See also, S. Swain, Hellenism and Empire (Oxford: Clarendon Press, 1998), pp. 223-24.

54 Merkelbach, pp. $290 \mathrm{ff}$.

55 Franke, p. 93. P.R. Franke notes that there are over 400 extant homonoia issues from around 160 different areas throughout the Greek East. 
have been interested in establishing lines of protocol and secure their places, since the provincial kotvóv was often a showcase for the power-configurations of the province. ${ }^{56}$
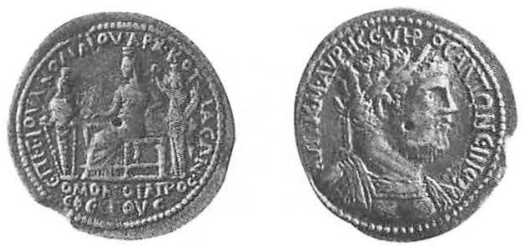

Divinities of Ephesus and Cotiaëum with goddess Homonoia standing on the right (Reproduced by the kind permission of the British Museum)

Generally, the homonoia coins tend to bear images which picture the personification of two or more cities and the announcement of the establishment of homonoia between the them..$^{57}$ Over 78 cities expressing more than 110 combinations of homonoia declarations testify to the broad use of this type of coinage during the Principate. ${ }^{58}$ It is not clear whether the frequent use of homonoia on these coins has religious connotations associated with the cult of homonoia, or whether they simply demonstrate political agreement between the named cities. Invariably, both economic and religious ties were advertised through the homonoia coins and often they represented the cessation of conflicts over primacy. 59

Ursula Kampmann's study of the coins of Pergamon indicate that many of the coins in the corpus which date from the first and second centuries A.D. for the cities of Pergamon, Ephesus, and Smyrna reflect the intense rivalry between these cities over the title of $\pi \rho \omega$ in

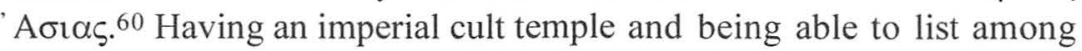

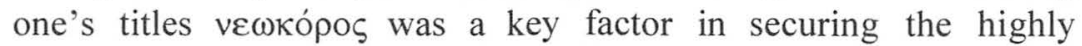
prestigious title $\pi \rho \omega \tau^{\prime}$ Aøı ${ }^{6} .{ }^{61}$ Pergamon highlighted the fact that it

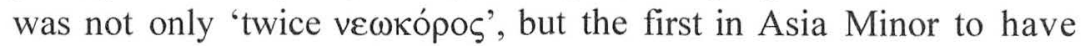
that title by virtue of its temple to Augustus.62 Some of the

56 Kampmann, Homonoia-Vereinbarungen, p. 21.

57 Franke, P.R. Kleinasien zur Römerzeit (München: C.H. Beck, 1968), p. 23.

58 Franke, p. 24.

59 Franke, p. 24.

60 Kampmann, pp. 375-76.

61 'Neokoros...became a coveted title in spite of early efforts in Asia to moderate its impact. The explosive spread of the term indicates not merely a new city title of local significance, but a fundamental shift in the identification of these cities... [that]...changed the public discourse of religion and identity in the eastern Mediteranean for centuries to come.' S. Friesen, 'The cult of the Roman Emperors', p. 236.

62 Die Altertümer von Pergamon, 8/2 (Berlin: 1890), §§438, 395. 
homonoia coins may reflect these changes in the ranking of the cities in the province and their attempts at negotiating their acceptance. ${ }^{63}$ The ranking of cities was important for the festivals and provincial councils in which an official procession from the imperial cult temple, a meeting of the delegates of the cities, and commonly a sacrifice at the temple altar, all made statements about which cities could lay claim to power in the province.64 Political harmony could often become the first victim at such joint sacrifices as the delegates from each of the cities asserted their claims over those of the others, with none being willing to compromise. ${ }^{65}$ The establishment of homonoia between the leading cities was therefore an important part of negotiating power within the political structures of Asia Minor during the first and second centuries. Along with other important social and political institutions like patronage and benefaction, homonoia politics were fundamental to inter-city diplomacy under Roman rule, and leading citizens along with most other segments of the population would have been familiar with the idea from their daily intercourse in trade, business, or simply from their handling of coinage.

The apostle Paul's preaching of the gospel fits in at the very beginning of the rise in inter-city rivalry in Asia Minor during the first century A.D. Although the full blossoming of these rivalries did not occur until the end of the first and the beginning of the second centuries A.D., it is likely that such sentiments were in the air. Opóvol $\alpha$ coins were first minted under Augustus between Smyrna and Pergamon, and re-appear during the reigns of Nero and Titus before becoming very common under Domitian. ${ }^{66}$ City rivalries, however, are attested much earlier and the internecine bickering of the first and second centuries A.D. are not new developments, but generally reflect the long history of competition and conflict between the Greek cities of the east. This was not unique to Asia Minor, but occurred throughout the Greek East, including the provinces of Cilicia and Bithynia. ${ }^{67}$ Political discord, social inequalities, and civic pride were all a part of the complex nature of the cities Paul visited, and especially of Asia's $\mu \eta \tau \rho o ́ \pi 0 \lambda \imath \varsigma$, Ephesus. How the political dimension of city life affected Paul is easily recognised in Luke's

63 Kampmann, p. 385.

64 Kampmann, p. 383.

65 Price, p. 130.

66 Kienast, 'Die Homonoia Verträge...', p. 64.

67 S. Mitchell, Anatolia, pp. 205-206. 
reconstruction of events in Acts 19:21ff. The riot caused by a leader of the local guild of silversmiths was only quelled by the city clerk ( $\gamma \rho \alpha \mu \mu \alpha \tau \varepsilon v \delta)$, but his words are revealing about the civic pride of Ephesians, and about the status of Ephesus throughout the

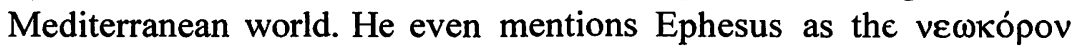

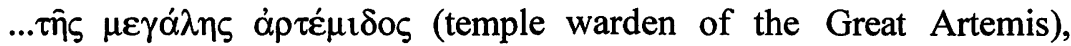
indicating the city's prestige in the province of Asia, as well as encouraging the crowds not to compromise their privileges before the Roman governor. ${ }^{68}$ Paul must have been aware of the importance of status, privileges, and titles to the Ephesians, and any subsequent leaders in the church at Ephesus would have had to contend all the more conscientiously with the powerful political instincts civic pride and inter-city rivalry awakened in Ephesus and its neighbours.

\section{Ephesians 1:21 and the struggle for primacy}

The thrust of C.E. Arnold's re-evaluation of power-language in Ephesians in light of the recently discovered Magical Papyri involves a complex assessment of the influences magical traditions. spells, and beliefs in the supernatural may have had on the many inhabitants of Ephesus. ${ }^{69}$ References in Acts 19:19 to sorcery and magical books confirm the importance of looking at other factors which may have shaped the world view of the average first century urban dweller that do not necessarily fall into traditional categories such as religious or historical influences. Political influences account for another important category of powerful cultural shapers which factored into the structure of first century A.D. society as well as such issues as political identity, social mobility, and historical continuity. Christians and members of other religious groups were also members of a society which understood itself primarily in political terms, even if the margins of power had shifted away from local and civil autonomy of the city governments during the Principate. The imperial cult is perhaps the most obvious contemporary example for understanding the inter-connectedness of the political and religious worlds. The struggle for power was a common characteristic of urban life in the first century, and though there were

68 See Acts 19:35-41 (NIV).

69 Arnold, Ephesians, Power and Magic, see Introduction. 
other forms of resistance, the struggle for primacy was still an important method for expressing identity and power. ${ }^{70}$

The themes of unity and oneness occur throughout the epistle to the Ephesians. ${ }^{71}$ But these themes do not occur against a neutral back-drop, rather, they are expressed as a revolutionary part of God's work of reuniting all things under the headship of Christ. ${ }^{72}$ The imagery here is intentionally provocative. Augustus had also been hailed as the world ruler under whose headship peace and prosperity had been secured, yet we know from the examples of the cities in Asia Minor in subsequent years that the Pax Romana was more often an ideal than a practical reality. In fact, social and political tensions were still major issues, and the unruly administrations of Caligula, Nero, and Vespasian stand as harsh reminders of the limits to peace at the height of Roman rule. ${ }^{73}$ Unity and oneness were themes that contemporary orators preached as well, stressing the importance of embracing homonoia instead of engaging in rivalries and disputes. ${ }^{74}$ The rise in the use of homonoia in popular slogans and in political speeches in the late first and early second centuries A.D. helps reveal the amount of discord that was current under the surface of political compliance to Rome, and the later involvement of

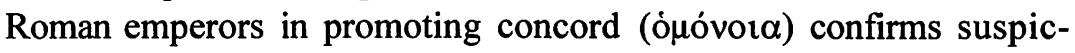
ions of a latent disunity at the local and provincial levels throughout the empire. 75

Unity is a pressing concern of the writer of Ephesians. This is an understandable concern when viewed against the back-drop of the increasing inter-city rivalry of the late first century, and helps broaden our understanding of some of the nuances the writer's choice of words and images could have had. C.E. Arnold has already alluded to some of the dimensions the 'power language' can have had in the context of the Magical Papyri, but it is also possible to see specific political images evoked and challenged as well. ${ }^{76}$ One such image occurs in Ephesians 1:21.

70 See S. Swain, Hellenism and Empire, pp. $187 \mathrm{ff}$.

71 Eph. 1:3-10; 2:11-22; 4:1-9; 4:14-16.

72 Eph. 1:10; See E.F. Scott, The Epistles of Paul (New York, 1930), pp. $146 \mathrm{ff}$.

73 The Jewish revolt and its suppression, which occurred in the later half of the first century A.D., is a forceful reminder of the fragility of the Roman Peace. See especially Josephus, The Jewish War.

74 Dio Chrysostom, Or. 3.8-40; Aelius Aristides, Or. 23.

75 Kampmann, Die Homonoia-Verbindungen, p. 34.

76 See Arnold, introduction. 
In the Thanksgiving and Prayer, the writer prays that the recipients would have the eyes of their hearts enlightened in order that they might know the hope to which God has called them, the riches of his inheritance in the saints, and his incomparably great power for believers. ${ }^{77}$ This incomparably great power the writer identifies as that same power which both raised Christ from the dead, and seated him at his right hand in the heavenly realms '...far above all rule and authority, power and dominion, and every title that can be given, not only in this present age, but also in the one to come.'78 In the context of the religious milieu of the first century, these are lofty assertions, but in the context of the political world, these were provocative and seditious words. In Plutarch's warning to the young political aspirant he conscientiously recommended that the supremacy of Rome in all affairs be acknowledged and not infringed upon, but here the writer of the epistle refuses to consign God's power merely to the realm of religion and the great hereafter, but situates Christ's supremacy fundamentally in the present age.79 Christ is seated far above all possible authorities and powers, as well as '...every title that can be given' ${ }^{80}$ To the listeners hearing these words, the titular rivalries between the leading cities of Asia Minor may have appeared as comparatively obvious examples of the meagreness of worldly power in light of Christ's heavenly supremacy, as well as the undeniable shortcomings of the many attempts to broker concord and peace in the name of homonoia. The best attempts at political unity were continually succumbing to the rivalries that broke out between the leading cities over the titles that Rome could give them, and very often the discord handicapped trade and generally dampened the well-being of the neighbouring cities.81 Political discord may even have been a form of resistance against Roman rule, and contemporary orators were aware of the compromises such protests could engender for a city. 82 Paul's prayer that the eyes of the believers hearts might be enlightened can be seen in direct contrast to the short-sightedness of the many rivalries that were constantly being pursued by the cities in their struggle to

77 Eph. 1:18-19.

78 Eph. 1:21.

79 Plutarch, Praec.Ger.Reip. (814C).

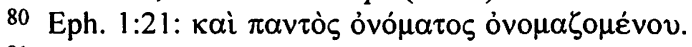

81 Dio Chrysostom, Or. 38.34; the rivalry between Nicomedia and Nicaea further disempowered both cities.

82 See Acts 19:35ff.; Dio Chrysostom Or. 38:36-38. 
secure the appearance of power and prestige, but which were often ways in which they further subjugated themselves to Roman manipulation.

In contrast to the precarious bonds of homonoia, the writer proclaims Christ as having permanently broken through the barriers and the 'dividing wall of hostility' that separated Jews and Gentiles (who were far less like one another than Ephesians and Smyrneans), and further, established peace between the discordant races in his own person. Throughout the epistle, the unity that God has established in Christ is defined in terms far superior to anything else, encompassing all things and being fulfilled in the Church, which is his body. ${ }^{83}$ In the ears of the hearers of the epistle, Christ through the Church and not the Emperor through his empire is the real source for hope for peace and unity, and the focus of the good news of the gospel of reconciliation and forgiveness. The message Paul and his followers proclaimed was one that extended throughout the dimensions of first century A.D. society, from religion through politics, and its stark contrasts between light and darkness, good and evil, this world and the one to come were no mere Gnostic metaphors, or the escapist fantasies of an apocalyptic sect, but were situated in the midst of the day to day intercourse of life in first century society where oppression, disempowerment, political ambition, compliance, resistance, and rebellion all had their share in forming the world-views of slaves as well as sophists. The mere titles that could be allocated to the politically emasculated cities of Asia Minor were shallow consolations in the light of Roman hegemony.

That Christ reigned in heaven at God's right hand, and that his power extended not only into the next age, but was rooted in the present one, could hardly have failed to escape comparison with the governors of provinces, or even the emperor, whose power and rule offered only timid promises of peace and empty slogans of harmony and concord.

83 Eph. 1:22-23. 